\title{
Legens plass i et kritisk mediebilde
}

\author{
Hvordan skal du som lege møte den tabloide pressen, når du har fått medienes kritiske søkelys \\ rettet mot deg?
}

Avisa Nordland (AN) er i tingretten dømt til å betale erstatning til kirurg Rastislav Kunda på grunn av avisens omtale av legen i forbindelse med den såkalte kirurgskandalen i 2010. Dommen er ikke rettskraftig, da Avisa Nordland har anket dommen. Selv om legen i dette tilfellet har vunnet frem over avisen, reiser saken et relevant spørsmål for leger: Hvorfor ble kirurgskandalen en så stor mediesak i 2010? Svaret er enkelt: Leger som gjør feil, er godt forsidestoff.

\section{Fra helt til skurk}

På samme måte som i et eventyr er en god nyhetshistorie (i tabloidavisene) gjerne bygd opp omkring en konflikt med en skurk, et offer og en helt. Vanligvis er pasienten offeret og legene har helterollen i mediene; de redder liv, gir pasientene et nytt og bedre liv eller oppdager nye behandlingsmetoder som redder enda flere liv. Eller så er legen eksperten som definerer sannheten rundt nordmenns helse i mediene. Det er nettopp den opphøyde rollen legene vanligvis innehar som gjør at avisene rydder forsiden når det motsatte skjer: når legene eller virksomheten de jobber for blir skurken og gjør det de ikke skal gjøre - bruker feil metoder, skader pasientene eller medvirker til at pasienter dør.

Hvordan skal en lege møte mediene i en situasjon hvor rollene er byttet om og legen ikke lenger er helten og eksperten?

\section{Vær menneskelig}

For det første må legen erkjenne hvilke rollen han eller hun har i mediesaken. Å tilnærme seg en sak hvor du som lege har skurkerollen, på en akademisk og distansert måte, vil fort bli feil. Å vise menneskelighet gjennom omsorg, ydmykhet og innrømmelser begren- ser kraften i fremtidige medieangrep, uten at mediene ukritisk skal brukes som en skriftestol. I mange uheldige mediesaker er det her legen bommer. Man tilpasser seg ikke situasjonen og går ikke ut av ekspertrollen.

\section{Vær åpen}

For det andre er åpenhet og ærlighet avgjørende. Taktisk tilbakeholding av informasjon vil kunne medføre at saken lever i mediene lenger enn nødvendig. Journalister har mange kilder og vil i de fleste

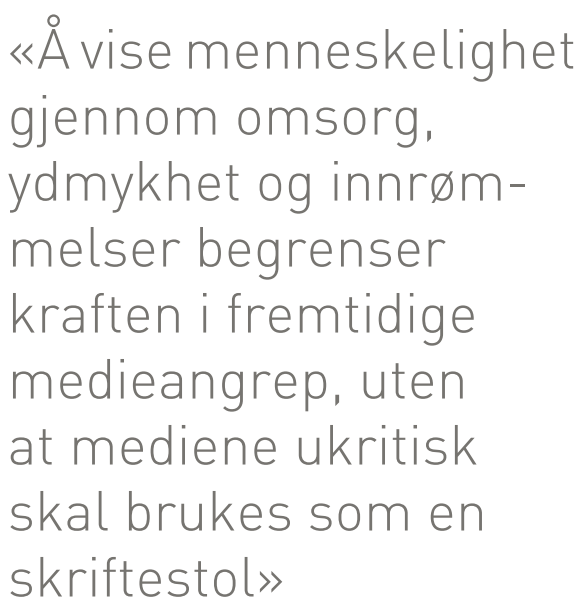

tilfeller kunne avdekke informasjon som er holdt tilbake. Åpenheten må naturligvis skje innenfor taushetspliktens begrensninger, men taushetsplikten må ikke brukes som et skjold man gjemmer seg bak.

\section{Trekk inn hjelp}

For det tredje må en lege som har fått medienes kritiske søkelys på seg, enten som leder eller som utøvende lege, snarest knytte til seg ressurser som kan bidra til å sette situasjonen inn i et mer objektivt perspektiv og som kan håndtere praktiske forhold rundt mediekontakten. Legeforeningen har ressurser som kan benyttes til dette. Det er i de første kontaktene at premissene for sakens videre utvikling legges. Blir du konfrontert av journalister i en kritisk sak, bør du ikke gi noen umiddelbare svar. Finn ut hva journalisten ønsker, og kom så tilbake til journalisten når du har fått klarhet i hva saken gjelder, hva du kan si, hva du bør si, hvordan du bør si det du skal si, og hva du ikke bør si.

\section{Carl Fredrik Bø}

cfb@effector.as

Carl Fredrik Bø er direktør i kommunikasjonsbyrået Effector - et reklame- og kommunikasjonsbyrå som blant annet jobber med medietrening og bistår klienter med medierådgivning og mediekontakt.

Forfatter har fylt ut ICMJE-skjemaet og oppgir følgende interessekonflikter: Han har vært rådgiver for Helse Sør-Øst RHF og underliggende helseforetak. Effector er et kommunikasjonsbyrå som blant annet bistår legemiddelindustriselskaper med mediehåndtering og medietrening.

Mottatt 21.3. 2013 og godkjent 4.4. 2013. Medisinsk redaktør Hanne Støre Valeur.

Publisert først på nett. 